Tyndale Bulletin 66.2 (2015) 161-196

\title{
DID PAUL INVENT JUSTIFICATION BY FAITH?
}

\author{
Hanna Stettler \\ (stettler-richter@gmx.net)
}

\begin{abstract}
Summary
Many researchers consider Paul's doctrine of justification a unique teaching, which he developed comparatively late, in his debate with judaising opponents of his Gentile mission. This article seeks to show that justification by faith without works can already be found in Paul's early writings and that Paul is by no means the first to teach it. Jesus, in his parable of the Pharisee and the tax collector found in Luke 18:9-14, taught it long before Paul, albeit in the shape of a story. The sentences Paul quotes in Galatians 2:16 and Romans 3:28 are not random remarks, but carefully phrased slogans which were handed down to Paul by those who were Christians before him. These sentences show an amazing verbal and conceptual congruity with the parable in Luke 18 and may well have been formulated on the basis of that parable. This seems all the more likely if we take into account that the parable was originally formulated in Aramaic and has a strong claim to authenticity.
\end{abstract}

\section{Introduction}

'Nowhere has Paul more fully entered into the heart of Jesus' teaching about God and man than in his insistence on justification by divine grace.' "Nowhere is the connection between Paul and Jesus so evident as here.' ${ }^{2}$ These are the words of two of the greatest NT scholars of the last century - the first being the British scholar F. F. Bruce, the

1 F. F. Bruce, Paul and Jesus (London: SPCK, 1977): 52.

2 Joachim Jeremias, 'Paul and James', ET 66 (1954-55), 368-371, esp. 369. Cf. William R. Farmer, who finds it possible 'to view much of Paul's deepest theological thought as reflecting influence from Jesus' parables' (Jesus and the Gospel: Tradition, Scripture, and Canon [Philadelphia: Fortress, 1982], 49). 
second the German Joachim Jeremias. Where two such giants agree, we have reason to dig deeper and see whether their suggestion might not have something to it.

Whereas Bruce cautiously confines his statement to the reality of justification (leaving it open whether the actual term was taken over from Jesus) $)^{3}$, Jeremias holds that

Paul's doctrine of justification is, $\ldots$ in matter and in language simply a development of our Lord's own preaching.... Jesus was the first to designate the acceptance of the sinner by God as $\delta 1 \kappa \alpha 1 o v \tilde{\sigma} \theta \alpha$, that is, as an anticipated eschatological acquittal. ${ }^{4}$

According to Jeremias, Paul adopted it from the tradition behind Luke 18:14, in the parable of the Pharisee and the tax collector.

Not everyone would agree with this view. There are several highly debated issues in NT exegesis that might stand in the way of so bold a statement. We will therefore proceed in the following way: first we will consider at what point in Paul's career justification emerges and what place it holds in his theology (section 2). Then we will look at Luke 18:9-14, giving special attention to the issue of its date and authenticity (3). After that we need to look at possible connections between Paul and Jesus in general (4), before comparing Luke 18 with the relevant Pauline texts (5.1) and investigating possible paths from Luke 18 to Paul (5.2). Finally we will consider the differences between the parable in Luke 18 and Paul's statements on justification (5.3).

\section{Early Pauline Statements on Justification}

\subsection{Justification in Paul's Early Writings}

At first sight it seems as if Paul's specific teaching on the justification of the ungodly 'by faith' and 'without works of the Law' was only expressed in his letters to the Galatians, the Romans, and the Philippians. This is one of the reasons why the central position of justification in Paul's theology has been put into question in recent years.

Bruce, Paul and Jesus, 53.

4 Jeremias, 'Paul and James', 369-70. 
Jörg Frey in an essay on the theology of justification in 1 Corinthians ${ }^{5}$ distinguishes three major phases of the criticism of the interpretation of Paul in the Reformation tradition:

1) According to the 19th century scholar William Wrede, 'justification by faith was simply a polemical doctrine designed to neutralize the theological threat posed by Judaism' at a certain period of Paul's missionary endeavours. ${ }^{6}$ In the same vein, Albert Schweitzer calls justification by faith 'a subsidiary crater' in Paul's understanding of the gospel, the centre being 'the mystical doctrine of redemption through the being-in-Christ'. ${ }^{7}$

2) These older views have been taken up by the "New Perspective on Paul'. Krister Stendahl, E. P. Sanders and others explicitly followed Schweitzer's view that what is central to Paul is not the forensic category of justification but the participatory category of 'being in Christ'. ${ }^{8}$ According to James Dunn, the problem Paul tried to solve with his teaching on justification in Romans and Galatians was not Luther's question how to find a gracious God, but how Gentiles can participate in God's covenant with Israel. According to the New Perspective, 'Paul's arguments against "works of the law" do not concern the issue of righteousness by obedience to the law, but simply Jewish badges of identity that separated Jews from the Gentiles', ${ }^{9}$ or as Dunn put it - 'national righteousness' ${ }^{10}$.

3) In the German speaking world, a third criticism has been brought forth, by Georg Strecker and Udo Schnelle. They claim that Paul only formulated his specific teaching on justification by faith as opposed to works of the law in the Galatian crisis, where it served as a polemical

5 Jörg Frey, 'Rechtfertigungstheologie im ersten Korintherbrief', in Saint Paul and Corinth: 1950 Years since the Writing of the Epistles to the Corinthians., ed. C. J. Belezos, Sotirios Despotis, and Christos Karakolis, 2 vols. (Athens: Psychogios, 2009), 1:549-585.

6 Alistair E. McGrath, 'Justification', in Dictionary of Paul and His Letters, ed. G. F. Hawthorne, R. P. Martin, and D. G. Reid, (Downers Grove, IL: InterVarsity, 1993), 523; William Wrede, Paulus (Halle: Gebauer-Schwetschke, 1904).

7 Albert Schweitzer, The Mysticism of Paul the Apostle, trans. William Montgomery (New York: Henry Holt, 1931), 225.

8 Krister Stendahl, Paul Among Jews and Gentiles (Philadelphia: Fortress, 1976), 2; E. P. Sanders, Paul and Palestinian Judaism (Philadelphia: Fortress, 1977), 474-510.

9 Peter Stuhlmacher, Revisiting Paul's Doctrine of Justification: A Challenge to the New Perspective (Downers Grove, IL: InterVarsity, 2001), 81.

10 James D. G. Dunn, 'The Justice of God: A New Perspective on Justification by Faith’, JTS 43 (1992), 1-22, esp. 11. 
doctrine against his judaising opponents. ${ }^{12}$ Since Schnelle does not find Paul's teaching on justification from Galatians and Romans represented in the Corinthian correspondence, he thinks that Galatians must be close to Romans chronologically as well.

According to Jörg Frey all three of these positions

converge in their supposition that the doctrine of justification as Paul formulates it in his letters to the Galatians and to the Romans is not fundamental to Paul's theology - neither on a historical nor on a material level. This amounts to a fundamental disparagement of its relevance to theology. ${ }^{13}$

Martin Hengel strongly recommends that one abstain from any linear reconstruction of Paul's doctrine of justification. ${ }^{14}$ Before his first missionary journey, Paul had 13 or 16 years to develop his theology, and wrote all his letters within 7 or - at the most - 10 years. When he meets the three $\sigma \tau \dot{v} \lambda \alpha 1$, the leaders of the early church, at the apostolic council in around AD 48, Paul already stands for 'justification by faith alone' and for the inability of the law to lead sinners to salvation. ${ }^{15}$ The essential development in Paul's theology must have taken place in those early years before the apostolic council.

According to Hengel the differences between his extant letters are not so much the result of a theological development, but more due to the necessary adaptations a gifted writer makes to the situation he addresses. ${ }^{16}$ Only where the ongoing validity of the Torah was an issue, did he speak about the Torah-critical implications of his teaching on justification. In Thessalonica, where there was no debate on the Law, and in Corinth, where enthusiastic anti-nomism threatened to discredit his former preaching on freedom, he did not. ${ }^{17}$

Following Hengel, Frey scrutinises Paul's Corinthian correspondence as a 'test case' for his opinion that the subject of

12 Georg Strecker, 'Befreiung und Rechtfertigung: Zur Stellung der Rechtfertigungslehre in der Theologie des Paulus', in Rechtfertigung: Festschrift für Ernst Käsemann zum 70. Geburtstag, ed. Johannes Friedrich, Wolfgang Pöhlmann, and Peter Stuhlmacher (Tübingen: Mohr, 1976), 479-508, esp. 507; Udo Schnelle, Wandlungen im paulinischen Denken, SBS 137 (Stuttgart: Katholisches Bibelwerk, 1989), 28-29.

13 Frey, 'Rechtfertigungstheologie', 558, my translation.

14 Martin Hengel and Anna Maria Schwemer, Paul between Damascus and Antioch:

The Unknown Years (London: SCM, 1997), 11-15.

15 Cf. Hengel and Schwemer, Paul, 11.

16 Hengel and Schwemer, Paul, 12-13.

17 See Hengel and Schwemer, Paul, 14. 
justification is neither limited to Romans and Galatians nor to the rejection of national righteousness. In the church at Corinth - a predominantly Gentile church - the whole question of the Law is not an issue. Nevertheless there are some passages that clearly presuppose Paul's full teaching on justification. Frey observes that 'the law is not only discussed in 2 Corinthians $3 \ldots$ but it is also mentioned in 1 Corinthians 9:20 where Paul describes the Jewish life as life viò vó $\mu$ ov and, most remarkably, in 1 Corinthians $15: 56$ ':18 'The sting of death is $\sin$, and the power of $\sin$ is the law. ${ }^{19}$ This remark is very close to the ideas of Romans 7. If it

is not a secondary gloss [and we have absolutely no textual reason to believe it is], it gives evidence that Paul was already capable to phrase the connection of Law, sin, and death when writing to the Corinthians. ${ }^{20}$

As a matter of fact, 1 Corinthians 15:56 is 'a short formula of Paul's justification theology'. Because of its rather enigmatic character it suggests 'that the community was aware of its deeper rationale'. ${ }^{21}$

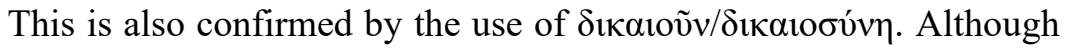
the apostle uses these terms in a rather unspecific way in 1 Corinthians, in 1:29-30 he does say that Christ being our righteousness excludes all boasting. This largely corresponds with the idea expressed in Romans $3: 27$.

The Corinthian correspondence thus shows that Paul's teaching on justification by grace alone and without works of the law was not only a polemical weapon designed to fight Jewish Christian opponents in the Galatian crisis, but lay at the heart of his theology. ${ }^{22}$

\subsection{Galatians as an Early Writing of Paul}

Those who believe that 'justification by faith and not by works' appeared rather late in Paul's theological thinking, tend (like Schnelle)

18 Frey, 'Rechtfertigungstheologie', 584, my translation.

19 Unless stated otherwise, all biblical quotations are taken from TNIV.

20 Frey, 'Rechtfertigungstheologie', 584, my translation.

21 Frey, 'Rechtfertigungstheologie', 585; my translation.

22 Similarly, David Wenham points out that 'justification/righteousness terminology does crop up at significant points in letters other than Romans and Galatians, for example, in 1 Cor. 1:30; 2 Cor. 5:20; and Phil. 3:9', (Paul: Follower of Jesus or Founder of Christianity? [Grand Rapids, MI: Eerdmans, 1995], 54). See also Ronald Y. K. Fung, 'Justification by Faith in 1\&2 Corinthians', in Pauline Studies Essays Presented to Professor F. F. Bruce on his 70th Birthday, ed. Donald A. Hagner and Murray J. Harris (Exeter: Paternoster, 1980), 246-261. 
to give Galatians a date somewhere near Romans, about AD 57. Such a late date presupposes the North Galatian hypothesis. This was until recently the consensus in German scholarship, ${ }^{23}$ while being questioned elsewhere, ${ }^{24}$ especially by a number of English speaking scholars. It is being abandoned by a growing number of German speaking scholars as well. ${ }^{25}$

According to the North Galatian hypothesis its addressees, the 'Galatians' (3:1), are the Gallic tribes living in the rather inaccessible north of the Roman province called 'Galatia', which was the territory of the former kingdom of Galatia. However, we do not have any clear evidence of Pauline churches in that area. Celtic speaking tribes here may not even have spoken Greek. Claims that in Paul's day 'Galatia' could only designate the former kingdom of Galatia in the North are not true. Inscriptional evidence shows that 'the name of Galatians was widely used as a designation for persons of Phrygian as well as Celtic origin' ${ }^{26}$ Since Paul liked to name his churches after the provinces they were located in (see 1 Thessalonians 1:7; 4:10; 1 Corinthians 16:15,19; 2 Corinthians $8: 1 ; 9: 2,4 ; 11: 10$; Romans 15:26; 16:5), and since in the case of Galatia no other name was available under which they could be joined together, it is much more likely that 'Galatians' was addressed

23 See, e.g., Udo Schnelle, Einleitung in das Neue Testament, 5th ed. (Göttingen: Vandenhoeck \& Ruprecht, 2005), 114-118.

24 For a balanced presentation of the arguments for both hypotheses see F. F. Bruce, The Epistle to the Galatians, NIGTC (Exeter: Paternoster, 1982), 3-18. For a detailed presentation of the history of research see Thomas Witulski, Die Adressaten des Galaterbriefes: Untersuchungen zur Gemeinde von Antiochia ad Pisidiam, FRLANT 193 (Göttingen: Vandenhoeck \& Ruprecht, 2000).

25 Among the German speaking scholars advocating the South Galatian hypothesis are: Cilliers Breytenbach, Paulus und Barnabas in der Provinz Galatien: Studien zu Apostelgeschichte 13f; 16,6; 18,23 und den Adressaten des Galaterbriefes, AGSU 38 (Leiden: Brill, 1996), 172-173; Hengel and Schwemer, Paul, 302-303; Rainer Riesner, Die Frühzeit des Apostels Paulus. Studien zur Chronologie, Missionsstrategie und Theologie, WUNT 71 (Tübingen: Mohr, 1994), 243-250; Peter Stuhlmacher, Biblische Theologie des Neuen Testaments, vol. 1: Grundlegung: Von Jesus zu Paulus, 3rd ed. (Göttingen: Vandenhoeck \& Ruprecht, 2005), 225-226; Witulski, Adressaten, 224.

26 G. Walter Hansen, 'Galatians', in Dictionary of Paul and His Letters, ed. G. F. Hawthorne, R. P. Martin and D. G. Reid (Downers Grove, IL: InterVarsity, 1993), 323-334, esp. 325, pace W. Bauer's Greek-English Lexicon s.v. 'Galatia'. The inscriptions Hansen quotes show that 'Galatians' can refer to places in the whole Roman province, not only in the Gallic kingdom of Galatia. The fact that the Church Fathers and - following them - exegesis in medieval and Reformation times propagated the north Galatian hypothesis, can be easily accounted for: the province of Galatia was reduced in size step by step, until by the 3rd century AD it was about the same size as the territory the original Celtic conquerors called 'Galatians' had inhabited (see Hansen, 'Galatians', 326). 
to the churches in the South of the province of Galatia, in other words the churches in Pisidian Antioch, Iconium, Lystra, and Derbe, which Paul founded on his first missionary journey (see Acts 13-14). ${ }^{27}$

If we follow the South Galatian hypothesis, the terminus post quem for the composition of Galatians would be Paul's first missionary journey to South Galatia, which took place between AD 45 and $47 .{ }^{28}$ The terminus ante quem would be the beginning of his second journey (around AD 52), for the letter seems to indicate that Paul only visited those churches once (Galatians 1:6; 4:13). It could have been written from Antioch, Corinth, or Ephesus. If Galatians 2 refers to the incident recorded in Acts 11:27-30, rather than Acts 15, this would date Galatians, including Paul's very clear statements on justification in this letter, before the Apostolic Council in AD 48/49. ${ }^{29}$

\subsection{Pauline Statements about Justification which are Really Pre-} Pauline

In several places in his letters, Paul indicates that the teaching on justification by grace was handed down to him by those who were Christians before him. The two clearest statements of justification by grace are to be found in Galatians 2:16 and Romans 3:28. ${ }^{30}$

That no human being is justified by works of the law but only through faith in Jesus Christ, is already a widely known theological principle when Paul quotes it in Galatians and Romans. ${ }^{31}$ It has a history before and apart from Paul's theology. One possible translation of Galatians 2:15-16 reads:

We are Jews by birth and not sinful Gentiles. ${ }^{16}$ (a) We knew (b) that a person is not justified by observing the law, (c) but by faith in Jesus Christ, (d) so we, too, put our faith in Christ Jesus (e) that we may be justified by faith in Christ and not by observing the law, (f) because by observing the law no one will be justified.

27 Cf. Hansen, 'Galatians', 326.

28 See Riesner, Frühzeit, 258.

29 Cf., e.g., I. Howard Marshall in I. Howard Marshall, Stephen Travis, and Ian Paul, Exploring the New Testament, vol. 2 (London: SPCK, 2002), 56-59; David Wenham, Paul and Jesus: The True Story (London: SPCK, 2002), 44-48. For a survey of the arguments brought forth for a date before or after the Apostolic Council see Hansen, 'Galatians', 327-329.

30 There are others like 'the saying quoted in 1 Corinthians $6: 11 \ldots$ [which] also seems to have pre-Pauline roots' (Stuhlmacher, Revisiting, 23).

31 Stuhlmacher, Revisiting, 23. 
Christoph Burchard is right to interpret Galatians 2:16 as the quotation of a well known principle, which Paul has already used as an argument in his confrontation with Peter in the conflict at Antioch: 'It is clear that in [verses 15-16] [Paul] resorts to a foundation that all who are part of the group called "we" acknowledge.' 33 This group comprises not only Peter and Paul but also the other Jewish Christians in Antioch. ${ }^{34}$ Therefore, this principle must have been universally acknowledged in the whole church of Antioch ${ }^{35}$ and Paul can remind Peter of it. It is most likely that Paul is saying that this is what he and the other Christians in Antioch knew when they became believers. If the

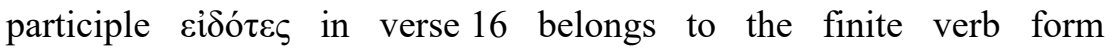
$\dot{\varepsilon} \pi ı \tau \varepsilon v ́ \sigma \alpha \mu \varepsilon v$, we have to interpret it as a past tense. ${ }^{36}$ This is how we

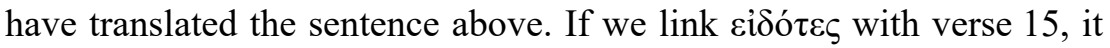
becomes a present tense and we get a somewhat different meaning:

We who are Jews by birth and not sinful Gentiles ${ }^{16} \mathrm{know}$ that a person is not justified by observing the law, but by faith in Jesus Christ. So we, too, have put our faith in Christ Jesus that we may be justified by faith in Christ and not by observing the law, because by observing the law no one will be justified.

This is how TNIV renders the sentence. However, the first option is more likely on syntactic grounds. ${ }^{38}$ The position of $\varepsilon i \delta o ́ \tau \varepsilon \varsigma$ at the beginning of the sentence seems to indicate that this was something Paul, as well as Peter and the Christians in Antioch knew before they

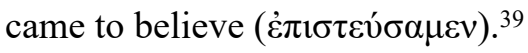

33 Christoph Burchard, 'Nicht aus Werken des Gesetzes gerecht, sondern aus Glauben an Jesus Christus - seit wann?', in Geschichte - Tradition - Reflexion 3: Frühes Christentum: Festschrift für Martin Hengel, ed. H. Cancik, H. Lichtenberger, and Peter Schäfer (Tübingen: Mohr, 1996), 405-415, esp. 406-407. See also Hengel and Schwemer, Paul, 208-209.

34 See Burchard, 'Nicht aus Werken', 407.

35 Since this is true of Jewish and Gentile Christians alike, 'not by works of the Law' cannot mean the rejection of Torah as a direction for life. It is not accidental that Paul does not reproach Peter for forcing the Jewish Christians to ioudaizein (again), but only the Gentiles. The Jews will not have stopped to adhere to the Torah. Therefore, justification by faith is not the opposite of obeying the Torah, but of trying to please God through Torah adherence without a relationship to Christ (cf. Burchard, 'Nicht aus Werken', 409-412).

36 Burchard, 'Nicht aus Werken', 407.

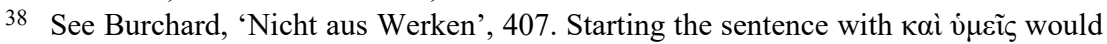
be somewhat odd.

39 Burchard, 'Nicht aus Werken', 407-408. 
In addition عíóó $\varepsilon \varsigma$ often serves as a tradition indicator in Paul. ${ }^{40}$ So in Galatians 2:16, عíó $\tau \varepsilon \varsigma$ ö $\tau$ m marks what follows as a common tradition, which had been in circulation not only before Paul wrote Galatians, but even before the Antioch incident. ${ }^{41}$ It makes Galatians 2:16b-c a general statement in the present tense, like Romans 6:9 and 2 Corinthians 4:14, not tied to any specific situation. ${ }^{42}$ This is confirmed by $2: 16 \mathrm{~d}$-e where Paul applies it to a specific group, that is, the Jewish Christians. That the statement as such is of general validity is underlined by the final proof text from Psalm 143:2 (2:16f) which speaks of $\pi \tilde{\alpha} \varsigma \zeta \tilde{\omega} v$ (Psalm 143:2) / $\pi \tilde{\alpha} \sigma \alpha \sigma \alpha ́ \rho \xi$ (Gal. 2:16f). ${ }^{43}$

It has often been argued that Paul learnt and understood the content of this statement in his experience on the road to Damascus. ${ }^{44}$ But Galatians 2:15-16 does not sound as if Paul was summarising what he learnt there.

In Romans 3:28 a similar statement about justification by faith ('for we maintain that a person is justified by faith apart from observing the

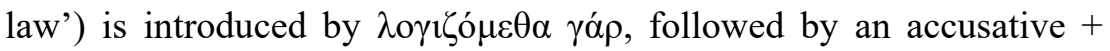
infinitive. There are no articles, the verb $\delta \iota_{1} \alpha 10 \tilde{\sigma} \sigma \theta \alpha$ is a present tense, and the subject of the whole sentence is 'man'. All this indicates that Romans 3:28, too, is a general statement that was already widely known and acknowledged. ${ }^{46}$

In both places, Paul uses these statements as a basis for his own argument. The fact that he can even expect the Christians in Rome to agree with this principle shows how universally it must have been accepted in the early church.

In Burchard's opinion, Paul must have known the traditional statement he renders in Galatians 2:16 from the Christians he persecuted, the so-called Hellenists. A next step would be to ask how did Peter and other Christians before Paul come to know it? These are questions Burchard does not fully answer. He considers it possible that

40 Michael Theobald, 'Der Kanon von der Rechtfertigung (Gal. 2,16; Röm 3,28) Eigentum des Paulus oder Gemeingut der Kirche?', in Worum geht es in der Rechtfertigungslehre?, ed. Thomas Söding (Freiburg: Herder, 1999), 131-192, esp. 136.

41 For the view that the principle in Gal. 2:16 is not an ad hoc formulation of Paul's, but pre-Pauline oral tradition, see also Theobald, 'Der Kanon', 135.

42 Theobald, 'Der Kanon', 136.

43 Theobold, 'Der Kanon', 138.

44 See Christian Dietzfelbinger, Die Berufung des Paulus als Ursprung seiner Theologie, 2nd ed., WMANT 58 (Neukirchen-Vluyn: Neukirchener, 1989), 114-116.

46 See Theobald, 'Der Kanon', 138-39. 
the sentence goes back as far as the Aramaic speaking church in Jerusalem, since Peter, who believed in Christ before the Hellenist church existed, knew it. ${ }^{47}$ In Burchard's opinion certain characteristics of Jesus's work on earth could well form part of its experiential background. Yet Burchard does not believe that this principle is of a pre-Easter origin. ${ }^{48}$

I would like to take Burchard's argument a step further by investigating more fully: What did Peter know about justification by faith?

\subsection{Corinthians 15:3-5 - an Early Christian Summary of the Gospel}

It is always difficult to assess what a person from antiquity might or might not have known. But in one place Paul tells us quite clearly what Peter knew: in the formula he quotes in 1 Corinthians 15:3-5.

It is true that in Galatians 1:11-12 Paul claims:

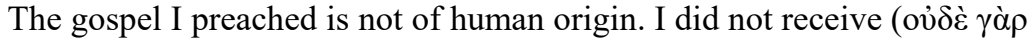
$\ldots \pi \alpha \rho \hat{\varepsilon} \lambda \alpha \beta$ ov) it from any human source, nor was I taught it.

So there is a sense in which his gospel was revealed to him directly. Yet in another sense (as far as its historical content is concerned) he did receive it as tradition from those who were Christians before him. ${ }^{49}$ Hence, in 1 Corinthians 15:3-5 he admits:

For what I received ( $\pi \alpha \rho \varepsilon \dot{\lambda} \alpha \beta$ ov) I passed on to you... ${ }^{50}$

This text formulates the content of the gospel in four parallel statements: ${ }^{51}$

47 Burchard, 'Nicht aus Werken', 408.

48 Burchard, 'Nicht aus Werken', 412.

49 See Bruce, Paul, 37: 'In counterpoise to the gospel as revelation in Paul's writings, stands the gospel as tradition. Whereas the gospel as revelation relates to the personal revelation of Christ to the apostle or to his discernment and disclosure of God's hidden purpose the gospel as tradition relates to historical facts, depending on the testimony of eyewitnesses.' Dietzfelbinger, even though he puts a lot of emphasis on the Damascus experience as the main source of Paul's theology, is right not to deny that Paul also received traditions from men (Die Berufung, 126).

501 Cor. 11:23 using a similar wording says that the tradition in question was

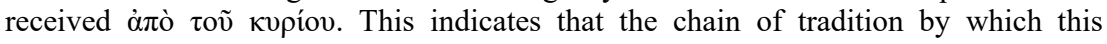
tradition was handed down to Paul originated with Jesus (while he was on earth).

51 There has been some debate as to the exact boundaries of the formula in 1 Cor. 15 with suggestions ranging from vv. 3-5 to 3-8 (see the detailed presentation of the research on this matter in Detlef Häusser, Christusbekenntnis und Jesusüberlieferung bei Paulus, WUNT 2.210 [Tübingen: Mohr Siebeck, 2006], 65-77, 90-91). For our 
1) Christ died for our sins according to the Scriptures;

2) and he was buried;

3) and he was raised on the third day according to the Scriptures;

4) and he appeared to Cephas, and then to the Twelve. ${ }^{52}$

This formula is certainly pre-Pauline for several reasons. First of all, Paul says so explicitly in verse $3 \mathrm{a}$, using Jewish technical terms for the transmission of tradition. ${ }^{53}$ Secondly, these lines contain several nonPauline expressions. ${ }^{54}$ And thirdly, they are formulated in Semitic style. ${ }^{55}$ Since all the witnesses named in verses 5-7 are associated with Jerusalem it is most likely that this formula was composed there. If Paul wanted to show that his gospel agreed with that of the Jerusalem apostles, as he says in 1 Corinthians 15:11, a formula that summarises tradition from Jerusalem was suited best for his purpose. Birger Gerhardsson rightly argues that Paul quotes this tradition as an authoritative $\pi \alpha \rho \alpha \dot{\delta} \delta \sigma ı \varsigma$ and that only the Jerusalem apostles (with Peter at the head) would have been entitled to formulate such a paradosis. ${ }^{56}$ Until the persecution under Herod Agrippa I in AD 43 (see Acts 12:1-17), they were the most suitable authority to formulate such a summary of the Christian message. ${ }^{57}$ This means that 1 Corinthians

purposes it is sufficient to note that almost all scholars agree that vv. 3-5 constitute the oldest part of the formula (Häusser, Christusbekenntnis, 154).

52 For a thorough study of this passage see Martin Hengel, 'Das Begräbnis Jesu bei Paulus und die leibliche Auferstehung aus dem Grabe', in Studien zur Christologie: Kleine Schriften, vol. 4, WUNT 201 (Tübingen: Mohr Siebeck, 2006), 386-450; Martin Hengel, 'Das Mahl in der Nacht, "in der Jesus ausgeliefert wurde" (1 Kor 11,23)' in Studien zur Christologie: Kleine Schriften, vol. 4, WUNT, 201 (Tübingen: Mohr Siebeck, 2006), 451-495.

53 Cf. Hermann L. Strack and Paul Billerbeck, Kommentar zum Neuen Testament aus Talmud und Midrasch, vol. 4 part 1, 8th ed. (Munich: Beck, 1986), 444.

54 See Stuhlmacher, Biblische Theologie 1, 168-169.

55 'Its distinguishing features include the parallelism of members, the second

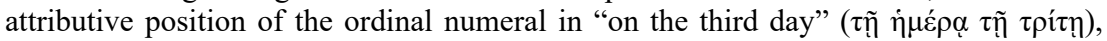
the divine passive $\dot{\varepsilon} \gamma \eta \dot{\gamma} \varepsilon \rho \tau \alpha$ ("he was raised") and possibly the use of $\ddot{\varphi} \theta \eta$ with dative (though this could also be due to the influence of the LXX) (Stuhlmacher, Biblische Theologie 1, 169; trans. Dan Bailey). The use of Kephas for Peter is not a valid argument, for this is the way Paul usually refers to Peter (Häusser, Christusbekenntnis, 86).

56 Birger Gerhardsson, Memory and Manuscript. Oral Tradition and Written Transmission in Rabbinic Judaism and Early Christianity, ASNU 22 (Uppsala: Gleerup, 1961), 297.

57 The events which are summarised in four short catchphrases will have been told in detail in Christian teaching. It is unthinkable that a summary like this would have been passed on without further explanations (Hengel and Schwemer, Paul, 17; see also Häusser, Christusbekenntnis, 106-141). 'The often-cited theory that vv. 3b-5 represents an Easter confession formulated independently of the Gospel passion tradition and 
$15: 3-5$ is a very early statement onwhich the early church universally agreed - a summary of what all Christians believed.

'In this ... formula, the death of Jesus is understood from the perspective of Isaiah 53:10-12 as death "for our sins". 58 At the same time Isaiah 53:8-11 is the nearest the OT ever gets to announcing the resurrection of an individual - of someone who has been executed for the sake of others at that. ${ }^{59}$ It is very likely that Jesus himself was the first to identify his own ministry with that of the Servant of the Lord. The eucharistic tradition as well as Mark 10:45 suggest such an identification on his part. ${ }^{60}$ This is of fundamental significance with respect to the origin of the theology of justification. For it is also in Isaiah 53 that an individual suffers and dies for the justification of 'the many' (53:11).

In Romans 4:25, another text which is based on Isaiah 53, Paul again seems to quote a traditional formula. ${ }^{61}$ Here the justification brought about by the vicarious death and the resurrection of the servant is mentioned explicitly. This means that, even before Paul, justification was linked to Christology on the basis of Isaiah 53:10-12. To my mind Stuhlmacher is entirely correct when he concludes:

The early Christian and Pauline doctrine of justification has taken up the interpretation of Jesus' sacrifice begun by Jesus himself with the help of Isaiah 53, and has further reflected upon it from a post-Easter perspective. ${ }^{62}$

without explicit interest in the historicity of Jesus' atoning death, burial, and resurrection appearances is incorrect' (Stuhlmacher, Biblische Theologie 1, 170; trans. Dan Bailey).

58 Stuhlmacher, Revisiting, 21. It is not clear which verse of Isa. 53 is in mind. The reference may well be to the text as a whole. Verses 4, 5, 6, 7, 10, and 12 all speak of the vicarious death of an individual for others (see Häusser, Christusbekenntnis, 98-99).

59 In the statement about the burial of Jesus, غ̇ंx́ $\varphi \eta$ could be an echo of Isa. 53:9, where the LXX mentions the $\tau \alpha \varphi \eta$ of the Servant (see Häusser, Christusbekenntnis, 99).

60 For the authenticity of Mark 10:45 see the discussion in Yongbom Lee, The Son of Man as the Last Adam: the Early Church Tradition as a Source of Paul's Adam Christology (Eugene, OR: Pickwick, 2012), 136-141. 'Paul reflects the early church tradition behind Mark 10:45 not only in Rom. 5:8, 15, 19 but also in Rom. 3:24; 4:25; 8:32; 1 Cor. 15:3; 2 Cor. 4:11; Gal. 2:20 (cf. Eph. 5:2,25)... There is no convincing reason to doubt that Paul knew about the early church tradition behind Mark 10:45, which interprets Jesus' atoning death with the image of 'ransom' in Isa. 43:3-4 and the language of Isa. 52:13-53:12, related to the Suffering Servant' (Son of Man, 123).

61 See Stuhlmacher, Biblische Theologie 1, 169-171.

62 See Stuhlmacher, Biblische Theologie 1, 129. 
So far we have seen that Paul's teaching on justification is present in his early writings (including Galatians), that it was taught by those who were Christians before him (Galatians 2:16 and Romans 3:28; 4:25) and that it goes back to Jesus's own interpretation of his death along the lines of Isaiah 53. We will now ask who was the first to use $\delta$ ¿ıนเoṽv in this way.

\section{Justification in the Jesus Tradition: The Parable of the Pharisee and the Tax Collector in Luke 18:9-14}

There is one incident in the synoptic tradition, and only one, where $\delta$ ¿ıcioṽv is used in a theological sense, that is, in the sense 'to be justified, to be put right (with God)' ${ }^{63}$ This is in the parable of the Pharisee and the Tax Collector in Luke 18:9-14, which concludes:

I tell you that this man, rather than the other, went home justified before God. For all those who exalt themselves will be humbled, and those who humble themselves will be exalted.

\subsection{General Observations}

The parable is preceded by a statement which directs the reader how to interpret it: Jesus told this parable 'to ( $\pi \rho$ ó $\varsigma$ ) some who were confident of their own righteousness and looked down on everyone else' (verse 9). This introduction seems to specify those the parable was directed at rather than the actual audience present. ${ }^{64}$ This would have included the Pharisees, reflecting one of the two main characters.

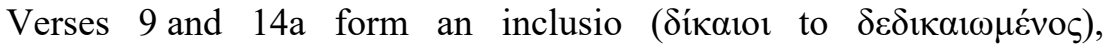
indicating the main interest of the whole parable: it is about who is righteous before God and who is not. In second Temple Judaism this was an important question to many, especially to the Pharisees (see Josephus, Jewish Antiquities 13:289; 14:176; Bellum judaicum 2:163).

63 Of its 6 other occurrences (Matt. 11:19; 12:37; Luke 7:29, 35; 10:29; 16:15), only Luke 10:29 and 16:15 come anywhere near the meaning 'acquit', but in both cases it is used of someone justifying himself.

64 " $\pi \rho$ ó $\varsigma$ may indicate the persons to whom the parable is addressed ... or possibly the people "against" whom it is directed (20:19)' (Marshall, Luke, 678). 
The meaning of the parable is clear: it draws a contrast between two people, a Pharisee and a tax collector, 'between self-righteousness and spiritual poverty or humility'. ${ }^{65}$

\subsection{Exegesis}

In his prayer in verse $11 \mathrm{~b}$, the Pharisee lists all the sins from which he has abstained; in verse 12 he enumerates his pious works that distinguish him from other people. They are opera superrogationis, that is, works that are done to make sure the law is fulfilled by going beyond its requirements. Whereas the law only prescribed one day of fasting per year, that is, on Yom Kippur, he fasts twice a week. Presumably this refers to the regular fasts kept by many Jews on Mondays and Thursdays (Didache 8:1). The second extra work the Pharisee mentions is that he tithes everything. The Torah obliges only the farmer who produced the food to tithe it. But the Pharisees, in order to make sure they would not eat any food that had not been tithed, tithed everything they bought again. ${ }^{66}$ The Pharisee in our story has sacrificed a lot in order to fulfil God's law.

The Pharisee's prayer has often been considered a gross exaggeration, but there are some astonishing parallels in early Jewish writings, like $b$. Berakhot $28 \mathrm{~b}$ and 1QH 7:34-35.

The prayer in $b$. Berakhot $28 b$ like the one in Luke 18:11 begins with thanksgiving for the person's own righteousness. Both of these early Jewish prayers express the expectation that the person who acts like the Pharisee will inherit eternal life, while those who act like the tax collector will perish.

Snodgrass is right when he says:

'Jews listening to Jesus would have assumed that the Pharisee was a righteous man'. His error is 'that he thinks he can be obedient to God and still have disdain for people like the tax collector — that is, that he can fulfil what the Torah demands with no attention to the love command'. Jesus frequently emphasized that one cannot be obedient to God's Law without loving one's neighbor as oneself, and he repeatedly challenged those who were certain of their good standing with God to reconsider. This parable expresses both themes. ${ }^{67}$

65 Klyne R. Snodgrass, Stories with Intent: A Comprehensive Guide to the Parables of Jesus (Grand Rapids, MI: Eerdmans, 2008), 468.

66 Matt. 23:23 and Luke 11:42 reveal that some even tithed herbs.

67 Snodgrass, Stories, 471-472. 
The tax collector, on the other hand, thinks of his sins, for which he seeks forgiveness (verse 13). He has made a lot of money by breaking the Law. It was a known fact that tax collectors not only collected the taxes for the pagan occupying power, which in itself was bad enough and would render them impure, but they also cheated and asked more than was lawful in order to make money for themselves (for example Luke $3: 13 ; 19: 8)$. Therefore, they are often referred to as 'tax-collectors and sinners' in the New Testament (for example Matt. 9:11; 11:19; Mark 2:15).

Attitudes toward tax collectors ... were quite negative. Such people were notorious for dishonesty and in the Mishnah are classified with murderers and robbers. ${ }^{68}$

The tax collector shows his remorse by his downcast position: he stands far away, ${ }^{69}$ lowers his gaze and beats his breast as a sign of his mourning over his sin. He calls himself a sinner and asks God to have mercy on him. The Greek text uses a passive form of i $\lambda \dot{\alpha} \sigma \kappa о \mu \alpha 1$, which means 'to reconcile', 'to render merciful', and also 'to atone' (for sins). In Hebrews 2:17 - the only other occurrence of the word in the New Testament - the high priest does this for the sins of the people. For a

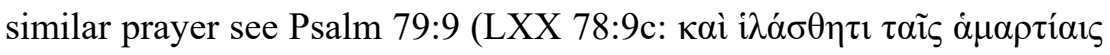

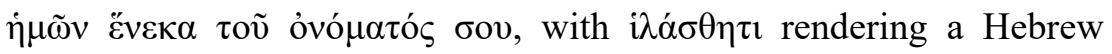
kapper, to atone).

There is some debate whether or not the prayers of the Pharisee and the tax collector are meant to take place during the time of sacrifice in the Temple at around three in the afternoon (compare Acts 3:1 and Didache 8:3 with Ezra 9:5; Dan. 9:21; Judith 9:1). If so, i $\lambda \alpha \dot{\sigma} \theta \eta \tau \iota$ may well be a reference to propitiation accomplished through sacrifice (rather than simply meaning 'have mercy on me'). There is no certainty with regard to the time of these prayers, but even if they took place at an unspecific time, Snodgrass is right to say that

the context of praying in the Temple, the place of God's presence and forgiveness, would still make one inclined to give i $i \alpha \dot{\sigma} \sigma \theta \eta \tau \imath$ its full weight as a term with 'sacrificial overtones'. The tax collector's prayer

68 Snodgrass, Stories, 467; cf. m. B. Qam. 10:2; see also Dio Chrysostomos, Orationes 14:14.

69 Cf. $m$. Tamid 5.6, according to which " "the unclean" were made to stand in the Eastern Gate' (Snodgrass, Stories, 468). 
is a poignant plea that the sacrifice will be effective enough to enable God to have mercy on him..$^{70}$

With or without sacrifice, the tax collector has no reason to hope for forgiveness, for he can never make the restitution decreed in Numbers 5:7 for all his fraud. ${ }^{71}$ His 'situation would be hopeless, for he could never know everyone he had wronged.' ${ }^{72} \mathrm{He}$ is a typical case of those for whom covenantal nomism does not provide. ${ }^{73}$ For the covenant only provides for unintentional sins, on condition that restitution be made. ${ }^{74} \mathrm{He}$ knows that he is facing imminent judgement.

As passages such as Zechariah 14, Joel 3, Malachi 4, the so-called Isaiah-Apocalypse in Isaiah 24-27, and Daniel 7 and 12:1-4 show, Israel and the nations are heading for an end-time judgment of God's wrath according to the Old Testament Jewish expectation. Only the saved community of God's elect will emerge from this judgment purified. ${ }^{75}$

Of this community the tax collector is not part. In recent years E. P. Sanders has promoted a view of Judaism which would make justification unnecessary for most Jews. If Judaism was a religion of covenantal nomism with a national eschatology, most individuals were simply not in need of salvation. The covenant itself supplied all that was needed to stay in it. But the important study of Mark A. Elliott, The Survivors of Israel, has shown that the Pseudepigrapha as well as the Qumran writings have taken over the expectation of a distinction in judgement within Israel from the early writing prophets. ${ }^{76}$ Because God's gracious covenants are always bound up with obligations for

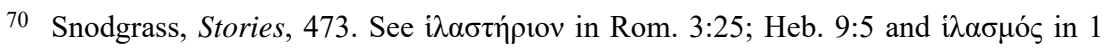
John 2:2; 4:10 (Stories, 744n187).

71 Num. 5:7 decrees that a person 'who wrongs another in any way ... must make full restitution for the wrong they have done, add a fifth of the value to it and give it all to the person they have wronged'.

72 Snodgrass, Stories, 468.

73 For a criticism of the presentation of Judaism under the heading of 'covenantal nomism' see Friedrich Avemarie, Torah und Leben, TSAJ 55 (Tübingen: Mohr, 1996) and 'Erwählung und Vergeltung: Zur optionalen Struktur rabbinischer Soteriologie', NTS 45 (1999), 108-126.

74 For a good summary of the limits of atonement in the OT see Christian Rose, 'Sühne, Sühnopfer', in Calwer Bibellexikon, ed. O. Betz and W. Grimm, 2 vols. (Calw: Calwer, 2003), 2:1286, who refers to Lev. 4:2; Num. 15:22-31. These limits of atonement spelled out in the Law might be the main reason why Paul denies that the Law was given unto salvation (Gal. 3:21; Rom. 8:3).

75 Stuhlmacher, Revisiting, 14.

76 Mark A. Elliott, The Survivors of Israel: A Reconsideration of the Theology of PreChristian Judaism (Grand Rapids, MI: Eerdmans, 2000). 
Israel, only the righteous will be saved. ${ }^{77}$ 'Early Judaism - across all the eschatologically oriented groups - sticks to righteousness according to works as a requirement for acquittal in judgment.' 78 This principle, combined with a growing awareness of $\sin$ in those days stood in tension to the election of Israel and the hope of God's grace for the elect. ${ }^{79}$ There are different solutions to this problem in the various groups of first-century Judaism. Some put more emphasis on grace, others on works. But they all share what Friedrich Avemarie has called 'aspective thinking' in Rabbinic Judaism — an attitude that holds together two seemingly contradictive views, namely grace and works ${ }^{80}$ There is one thing, however, about which the Pseudepigrapha as well as the Qumran writings are very clear: God does not have mercy on the wicked, but only on those who are (relatively) righteous and keep the law. ${ }^{81}$ Simon Gathercole rightly concludes:

Final salvation according to works is not a diaspora tenet that emerges in the Palestinian literature only after the crisis of the destruction of the temple: it is an integral part of the theology of Palestinian Judaism by the second-first [century] B. C. E. at the latest. ${ }^{82}$

In the Jesus tradition we can see very clearly that Jesus did not presuppose a covenantal nomism of the kind E. P. Sanders advocates. He clearly held that every Jew stood in need of salvation. Why else would he pronounce woes on

those who do not see themselves as in need of Jesus' acceptance of 'the poor' ... upon unrepentant rich people (Luke 6:24-25), teachers of the law (Luke 11:52/Matthew 23:13), and the cities of Chorazin, Bethsaida, and Capernaum that resisted his message (Luke 10:13-15/Matthew $11: 20-24) ?^{83}$

\footnotetext{
77 See Christian Stettler, Das letzte Gericht: Studien zur Endgerichtserwartung von den Schriftpropheten bis Jesus, WUNT 2.299 (Tübingen: Mohr Siebeck, 2011), 177.

78 Stettler, Gericht, 178, my translation.

79 Stettler, Gericht, 178.

80 Avemarie, 'Erwählung und Vergeltung'.

81 See Stettler, Gericht, 158. According to George Nickelsburg 'the righteous is not a person who never sins, but one who acknowledges his or her sin and God's righteous judgment of them and who atones for them by means of prescribed rituals' (Ancient Judaism and Christian Origins: Diversity, Continuity, and Transformation [Minneapolis, MN: Fortress, 2003], 43).

82 Simon Gathercole, Where is Boasting? Early Jewish Soteriology and Paul's Response in Romans 1-5 (Grand Rapids, MI: Eerdmans, 2002), 160.

83 Stuhlmacher, Biblische Theologie 1, 89; trans. Dan Bailey.
} 
According to verse 14a the tax collector is justified as an answer to his prayer, while the Pharisee is not. This must have been

'stunning for Jesus' hearers', it 'would contravene everything they knew'. He 'called a man righteous who was known to be unrighteous and refused this description for a man whom everyone would recognize as a righteous person' ${ }^{84}$

Why the tax collector is justified while the Pharisee is not is not stated, unless we take verse $14 \mathrm{~b}$ to be part of the original parable. But by way of implication it is clear that he is accepted because he shows an awareness of his need for the mercy of God who forgives sinners. The Pharisee, on the other hand, is rejected, because God does not accept works which conform to the law outwardly but are done without compassion and love as righteous.

Verse 14b speaks of God's action in final judgement: he will reverse the present order and humble the haughty while he will lift up the humble. Whether or not this statement was originally part of the parable does not make much of a difference, since it only underlines what the parable without it has already made sufficiently clear.

With his parable Jesus shows that this is how God is and, we can infer from the situation, this is how he acts through Jesus, his representative. For it is important for us to note who is telling this parable. Verse 14a introduces the statement about justification with an emphatic $\lambda \dot{\varepsilon} \gamma \omega \dot{v} \mu \tilde{v}$. It is Jesus who tells this story. Originally his story and life setting supplied the context for this parable. That means that the justification of the ungodly is tied to Jesus's ministry. He grants them forgiveness just like God does in the parable. ${ }^{85} \mathrm{He}$ can do so only as the servant of God who is about to die for the sins of 'the many' and their justification, according to Isaiah 53.

\subsection{Indications of the Origin of the Parable}

With Jeremias we can say that the language of this parable as well as its content reveal its origin in 'early Palestinian tradition.'86 Jeremias has pointed out a number of Semitisms, which are not typical of Luke's own style, but prominent in some of his source material:

\footnotetext{
84 Snodgrass, Stories, 468, 473-474.

85 Peter Stuhlmacher, Gerechtigkeit Gottes bei Paulus (Göttingen: Vandenhoeck \& Ruprecht, 1966), 245.

86 Jeremias, Parables of Jesus, revised ed. (London: SCM, 1963), 140.
} 
In the first place this parable contains more asyndeta than any other Lukan parable (verses $11,12,14) .{ }^{87}$ Luke in his own style does not use this feature as frequently.

Secondly, the position of $\pi \rho$ ò $\dot{\varepsilon} \alpha v \tau o ́ v$ (to himself) in verse 11 is uncertain in the textual tradition. The sentence could either read: 'He stood and prayed this by himself', ${ }^{88}$ or 'He stood by himself and prayed this' ${ }^{89}$ The first reading is slightly better attested by the external evidence of the manuscripts. However, 'it is unlikely the intent is that the Pharisee prays silently', since 'people in antiquity usually prayed aloud'. ${ }^{90}$ 'He stood by himself and prayed this' is the more difficult reading and could account for the omission of the phrase in some manuscripts. According to Marshall, ' $\pi \rho$ òs Éavtóv should be understood as representing an Aramaic ethic dative, which emphasises the verb: "The Pharisee, taking his stand, prayed"". ${ }^{91}$ If the original reading contained a Semitism that was difficult to understand in Greek, some manuscripts may have tried to ameliorate the text by changing its word order, others by omitting the unintelligible phrase, while D

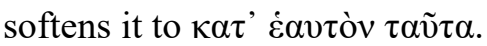

A third Semitism is the use of the negated verb $\ddot{\eta} \theta \varepsilon \lambda \varepsilon v$, 'he did not want to', in the sense of 'he did not dare to' in verse 13. Since some Aramaic dialects have no word for 'to venture', negated $\theta \varepsilon \lambda \varepsilon i v$ is sometimes used in this sense, as for example in Mark 6:26; Luke 18:4; John $7: 1 .^{92}$

Fourthly, the statement in verse 14, that the tax collector 'went

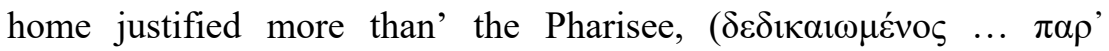
$\dot{\varepsilon} \kappa \varepsilon i v o v),{ }^{93}$ shows the Semitic background of this story in two ways: it is a divine passive, which is used in order to avoid the name of God, and it renders a Semitic comparative, min. Literally it means that

87 Cf. Jeremias, Parables, 140, referring to Matthew Black, An Aramaic Approach to the Gospels and Acts, 3rd ed. (Oxford: Clarendon, 1967), 59-60.

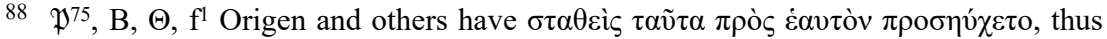

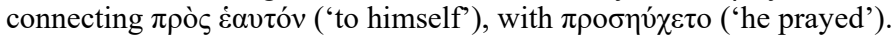

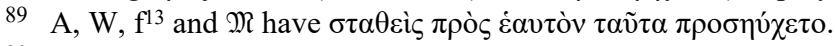

90 Snodgrass, Stories, 470.

91 Ian Howard Marshall, The Gospel of Luke, NIGTC (Exeter: Paternoster, 1978), 679, referring to Black, An Aramaic Approach, 103-104, 299 and Jeremias, Parables 140.

92 Cf. Jeremias, Parables, 141, referring to Paul Joüon, L'Évangile de Notre-Seigneur Jésus-Christ (Paris: Beauchesne, 1930), 216.

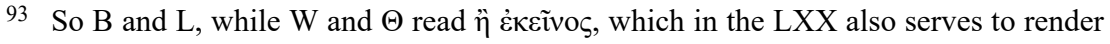
a Hebrew min. 
someone 'is justified more than another', which in Semitic languages can have the exclusive sense of: 'he and not another' ${ }^{94}$ This use of $\pi \alpha \rho \alpha$ is not part of Luke's own style. The only other place where he uses $\pi \alpha \rho \alpha ́$ in this manner is in another logion of Jesus in Luke 13:2, 4. There is no occurrence in Acts. Paul occasionally uses $\pi \alpha \rho \alpha ́$ in a

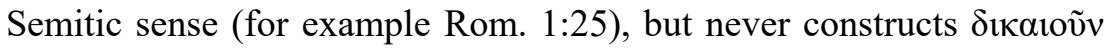
in this way.

\subsection{Coherence of the Parable with Jesus's Ministry and Teaching}

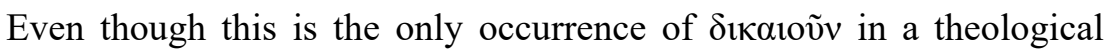
sense in the extant Jesus tradition, it is not an isolated one by any means. Jesus's whole ministry and teaching is penetrated with the justification of the ungodly by grace and faith. According to David Wenham,

[one] of the most prominent aspects of Jesus' ministry that distinguishes it from the ministry of similar religious leaders was his mixing and eating with sinful people. Scholars who are otherwise extremely cautious about the historical reliability of the Gospels have recognized this as historically authentic. ${ }^{95}$

This coherence with Jesus's ministry strengthens the parable's claim to authenticity. Other texts stating Jesus's focus on mercy and forgiveness include the unforgiving servant (Matt. 18:21-35), the Beatitude concerning the (spiritually) poor (Matt. 5:3; Luke 6:20), the parables about the two debtors (Luke 7:41-43), the labourers in the vineyard (Matt. 20:1-16) and the Prodigal Son (Luke 15:11-32). Interestingly, Jesus's defence of his conduct against his critics in Mark 2:17 and parallels contains the same contrast as Luke 18:14a and Paul's classical statements on justification: not the righteous, but sinners.

\footnotetext{
94 See Gen. 38.26 LXX and 2 Sam. 19:44 LXX for a Hebrew min rendered with and Ps. 45:8 (LXX 44:8) for a similar construction with $\pi \alpha \rho \alpha$. Cf. Jeremias, Parables, 141-142. In Gen. 38:26 Judah says about his daughter in law Tamar: 'tsadeqah

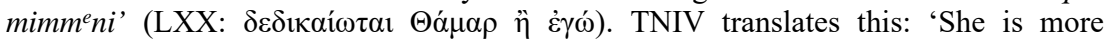
righteous than I'. But from the context it is quite clear that the meaning is: 'She is right(eous), while I am not'. This, of course, is not to be taken in an absolute sense, but with respect to the issue at hand.

95 Wenham, Follower, 44.
} 


\section{Jesus and Paul}

Both F. F. Bruce and J. Jeremias seem to imply a historical connection between Jesus and Paul rather than just some coincidental concurrence of ideas. However, such an assumption is not universally accepted. Some would say that even if Jesus did utter such a parable, it is most unlikely that Paul knew it. His letters do not show much knowledge of Jesus tradition.

Basically, there are three different positions concerning the nature of the connection between Paul and Jesus: ${ }^{96}$

1) Some believe that there is hardly any historical continuity and no significant theological congruity between them. ${ }^{97}$ One of the most recent examples of such a position is Andreas Lindemann's article on Paul and the Jesus tradition. ${ }^{98}$

2) Others, following Bultmann, hold that while there is not necessarily a historical continuity, there is significant theological congruity between Jesus's proclamation of the kingdom and Paul's teaching on justification. E. Jüngel's book on Paul and Jesus might be classified here..$^{99}$

3.) A third group - mostly, but not exclusively from the English speaking world - sees a historical continuity leading to theological congruity. To them, the few quotations from Jesus tradition in Paul are but the tip of the iceberg. ${ }^{100}$ Paul is considered a 'Follower of Jesus', not 'the Founder of Christianity', to use the words of David

\footnotetext{
96 For a survey of the history of research on this issue see Frank Holzbrecher, Paulus und der historische Jesus: Darstellung und Analyse der bisherigen Forschungsgeschichte (Tübingen: Francke, 2007); Häusser, Christusbekenntnis.

97 See section 1 of the Appendix.

98 Andreas Lindemann, 'Paulus und die Jesustradition', in Jesus, Paul, and Early Christianity: Studies in Honour of Henk Jan de Jonge, ed. R. Buitenwerf, Harm W. Hollander, and Johannes Tromp, NTSup 130 (Leiden: Brill, 2008), 281-316.

99 See section 2 of the Appendix. Interestingly, Jüngel does not treat Luke 18:9-14 in his book. Herbert Braun explicitly denies that there could be a historical or tradition historical bridge from this particular parable to Paul, even if there is a parallel in substance: ('Hebt die heutige neutestamentlich-exegetische Forschung den Kanon auf?', in Gesammelte Studien zum Neuen Testament und seiner Umwelt (Tübingen: Mohr, 1962), 310-324, esp. 315-316).

100 See section 3 of the Appendix.
} 
Wenham. ${ }^{101}$ One of the latest advocates of this position on the German side is Detlef Häusser. ${ }^{102}$

Below, I will present some of the arguments these scholars have brought forth. For the moment it is sufficient to realise that there is no unanimity on this subject. Therefore a dependence of Paul on Jesus tradition can neither be presupposed nor precluded.

\section{A comparison between Luke 18 and Galatians 2:16/Romans 3:20-28}

\subsection{Similarities between the Parable in Luke 18 and Galatians 2:16/ Romans 3:20-28}

Comparing the parable to Galatians 2:16 and Romans 3:28 we find significant parallels both conceptually and verbally. As far as verbal agreements are concerned, the parallels might not seem very impressive at first sight. The pre-Pauline formulae about justification and the parable of Jesus agree in only one word: the divine passive of $\delta$ ¿ $\alpha 10$ ṽv. ${ }^{103}$ This is a very significant agreement, however, because the justification of an ungodly person is not commonly expected in early Judaism. Even Genesis 15:6, which does speak of justification by faith,

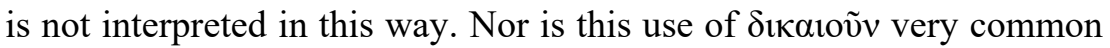
in the other NT writings. Within the Jesus tradition, Luke 18:14 is the only example. Outside the commonly accepted Pauline letters, Titus 3:7, Acts 13:39, and James 2:21, 24-25, which is a critical reply to Paul, are the only other occurrences.

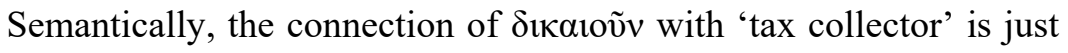

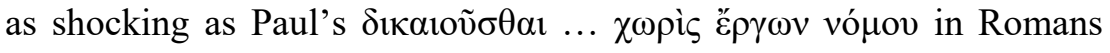

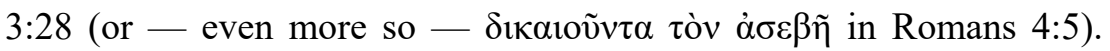
Paul, like the parable, uses $\delta \iota_{\alpha} \_$เov $\sigma \theta \alpha$ in a synthetical sense: the sinner God justifies has no righteousness in himself. If we compare this

\footnotetext{
${ }^{101}$ Compare the title of Wenham's book on Jesus and Paul with the similar title of Adolf Schlatter's commentary on 1 Corinthians: Paulus, der Bote Jesu. Eine Deutung seiner Briefe an die Korinther (Stuttgart: Calwer, 1934).

102 See Häusser, Christusbekenntnis.

103 Gal. 2:16 and Rom. 3:20 - quoting Ps. 142:2 LXX — both use the future tense of

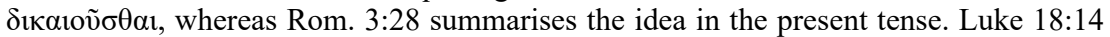
uses the perfect participle, because in the course of the parable justification becomes an accomplished fact.
} 
to James's use in $2: 21,24-25$, we can see that this was not self-evident within early Jewish Christianity. James (like Judaism) speaks of justification in an analytical sense: 'Was not Abraham / was not Rahab justified by works?' This is merely a statement about God recognizing the fact of their existing righteousness, whereas 'Paul, when speaking of ... justification, nearly always has in mind justification at baptism where the ungodly is declared by God to be righteous'. ${ }^{104}$

Conceptually, there is even greater agreement: even though the

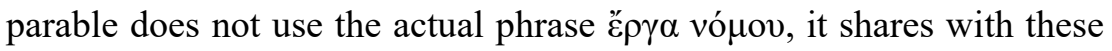
texts the idea that such works do not gain divine acquittal. Instead of using the technical term हैpy $\alpha$ vó $\mu$ ov, the parable gives examples of such works of the Law. Incidentally, the works of the Law the Pharisee in the parable mentions are not the typical identity markers such as Sabbath keeping, circumcision, and food laws, which separated Jews from Gentiles. He speaks about fasting and tithing. Since both of the characters in this parable are Jewish, it is clear that the issue is not Jewish nationalism or particularism, but the attempt to gain God's acquittal through works of the Law. ${ }^{105}$

In a similar vein, Luke 18 does not speak of faith explicitly, but the

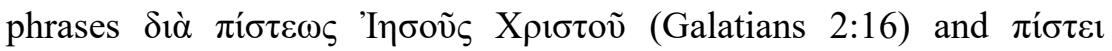
(Romans 3:28) describe the attitude of the tax collector, who does not count on his works but on the mercy of God alone. In Luke 18:8, which is also part of Luke's special material and immediately precedes our parable, $\pi i$ ítı is used in the absolute way we normally associate with Paul: God 'will see that they [his chosen ones] get justice, and quickly. However, when the Son of Man comes, will he find faith on the earth?' 106

\footnotetext{
104 Jeremias, 'Paul and James', 371. According to Jeremias, Paul's second use of justification is of a justification in judgement on the works brought forth by faith.

${ }^{105}$ See the presentation of the positions of J. D. G. Dunn and F. Watson in Thomas R. Schreiner, 'Works of the Law', in Dictionary of Paul and His Letters, ed. G. F. Hawthorne, R. P. Martin, and D. G. Reid (Downers Grove, IL: InterVarsity, 1993), 976. If the parable in Luke 18 is older and more original than Paul's teaching on justification, we have reason to doubt that the rejection of works of the Law for salvation has anything to do with the rejection of Jewish nationalism. According to Schreiner "Paul thought "works of the Law" did not save because a shift had taken place in salvation history and because human beings could not keep the Law' ('Works of the Law', 977).

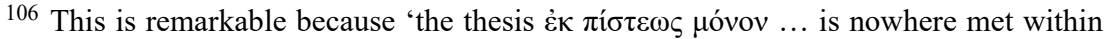
the whole literature of Judaism and of the earliest Christianity except only in Paul' (Jeremias, 'Paul and James', 368).
} 
The exclusive contrast the parable draws between the Pharisee, who has tried to keep the law and did not go home 'justified', and the tax collector, who has not kept it, but went home justified, can be summarised aptly with the phrase found in Galatians 2:16: iv $\alpha$

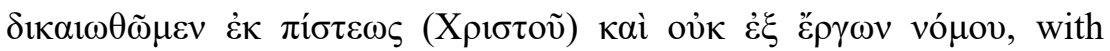

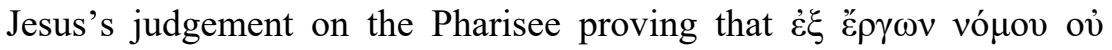
$\delta ı \alpha \iota \omega \theta \eta ் \sigma \varepsilon \tau \alpha \iota \pi \tilde{\alpha} \sigma \alpha \sigma \alpha ́ \rho \xi$ (Romans 3:28). It is therefore very likely that Luke 18:9-14 stood behind the formulation of this principle.

In Romans 3:20 Paul says that consciousness of sin comes through the Law. Whether the tax collector's conviction of sin comes through the law is not stated explicitly in Luke, but the setting of the whole scene in the Temple suggests it.

If we look at the verses between Romans 3:20 and 3:28, more parallels become visible. Luke's introduction to the parable reads: 'To some who were confident of their own righteousness and looked down on everyone else, Jesus told this parable.' Whether this introduction is original or not, it is certainly adequate, for boast the Pharisee does when he thanks God that he is better than other people and especially than 'this tax collector' (Luke 18:13). It is interesting to note that this is not the sarcastic depiction of Judaism by some ignorant Gentile Christians, but part of a tradition that was originally formulated in Aramaic, as the Semitic style of the parable shows. It clearly shows that righteousness by works of the Law was an issue in first-century Judaism.

Paul seems to echo this theme of self-confidence in Romans 3:27, when he asks: 'Where, then, is boasting? It is excluded. Because of what law? The law of works? No, because of the law of faith.' The attempt to gain righteousness through the Law inevitably leads to boasting, because God needs to be informed of the good works on the basis of which he should acquit a person. Such boasting, however, is always false boasting, because it is a boasting of people who have not actually kept the law perfectly. Therefore, any attempt to earn righteousness by obedience to the Law must fail. "No one can earn or merit right standing with God by obeying the Law.' ${ }^{107}$ In the same way, Jesus denies justification to the Pharisee in the parable, who thinks he is blameless as far as the Law is concerned but - we can infer - is

107 Schreiner, 'Works of the Law', 978. 
not. ${ }^{108}$ Jesus's judgement on the Pharisee despite his seeming righteousness presupposes that all have sinned and fall short of the glory of God, as Paul puts it in Romans 3:23.

We can observe another interesting detail here: In his prayer, the tax collector says: 'God, have mercy on me, a sinner (Luke 18:13).' As we have seen, we can argue that $i \lambda \alpha ́ \sigma \theta \eta \tau 1$, the term translated as 'have mercy on me', might have sacrificial overtones. This would make it a reference to propitiation. In Romans 3:24-25, the concept of justification by grace and atonement are closely connected. It is 'through the redemption that came by Christ Jesus', our i $\lambda \alpha \sigma \tau \eta$ piov, that is, our 'place of atonement' that those who believe 'are justified freely by his grace'.

So while we cannot prove that Paul actually knew the parable in Luke 18, the connection he makes between justification by faith alone and the exclusion of boasting as well as the connection between the justification of the ungodly and atonement could be explained given this background.

\subsection{Accounting for the Similarities between the Parable and Paul's Teaching}

In principle there are four possibilities to account for the similarity of Luke 18 and Paul's teaching on justification.

\section{1) Luke took it over from Paul}

This can be ruled out right from the beginning, for - as we have seen - the language of this parable reveals its origin in the early Palestinian

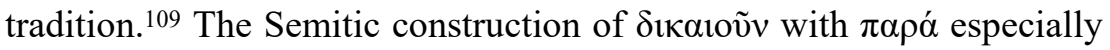
stands against a dependence on Paul, for Luke would have had to 'have altered a thesis of Paul formulated in fluent Greek to a bad semitizing Greek'. ${ }^{110}$ Also, it is very unlikely that Luke turned an abstract teaching into a vivid story.

\footnotetext{
${ }^{108}$ His disdain for the tax collector shows that he does not share God's compassion for sinners.

109 Jeremias therefore believes that 'Jesus was the first to designate the acceptance of the sinner by God as dikaiousthai, i.e., as an anticipated eschatological acquittal' ('Paul and James', 369).

110 Jeremias, 'Paul and James', 369. Cf. Marshall, Luke, 680: 'the language [i.e., this

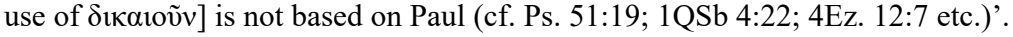




\section{2) The similarities are mere coincidence}

Given the extraordinary content of the parable such a coincidence is very unlikely. As we have seen, there are several significant agreements both verbally and conceptually, between the parable and Paul's teaching on justification, which are not coherent with firstcentury Judaism.

It has often been observed that Paul himself experienced 'justification of the unrighteous' before Damascus. ${ }^{111}$ But Strecker is right when he points out that Paul does not describe his own call in justification terminology. ${ }^{12}$ Philippians 3:7-8 speaks of Christ as surpassing all Paul once held dear. In verse 9 he speaks of the new righteousness, but this verse does not seem to refer to his calling but to 'Paul's ultimate aims'. ${ }^{113}$ There would have been many other ways to describe and express his Damascus experience. A statement like Romans 15:7, that 'Christ accepted' us, would have suggested itself for this purpose. It is not at all clear why justification would have been given so prominent a place in Paul's teaching if it had not been handed down to him. Kim Seyoon rightly argues that Paul received the basic gist of his gospel at his encounter with the risen Christ on the Damascus Road. ${ }^{114}$ Yet he admits that this does not mean 'that there and then he explicitly obtained his whole theology as seen in his letters'. Hengel, who also firmly believes that Paul received his gospel before Damascus and taught about justification as early as his mission

111 Cf. Ulrich Wilckens, 'Die Bekehrung des Paulus als religionsgeschichtliches Problem', ZThK 56 (1959), 273-293; Dietzfelbinger, 'Die Berufung', 114-116; Martin Hengel, 'Die Stellung des Apostels Paulus zum Gesetz in den unbekannten Jahren zwischen Damaskus und Antiochien', in Paulus und Jakobus: Kleine Schriften, vol. 3, WUNT 141 (Tübingen: Mohr Siebeck, 2002), 213.

112 Strecker, 'Befreiung', 481. However, I entirely disagree with Strecker's conclusion that Paul's Damascus experience did not have to lead to a criticism of the Law in the sense of Paul's teaching on justification ('Befreiung', 481n21). Strecker's arguments against the view that Paul persecuted the Hellenists because of their Law-critical position are not convincing. (In Strecker's judgement the hints in Acts 6:11-14 as well as Stephen's speech in Acts 7 are but redactional remarks in which Luke takes up Synoptic material or later Jewish Hellenistic theology respectively ['Befreiung', 481]). Nor does it follow that Paul's Law-critical position is a late development. As we shall see it is most likely that the tradition of the early church helped him to express Christ's acceptance of sinners as justification by faith very early.

113 Peter O'Brien, The Epistle to the Philippians, NIGTC (Grand Rapids, MI: Eerdmans, 1991), 391.

${ }^{114}$ Kim Seyoon, The Origin of Paul's Gospel, WUNT 2.4 (Tübingen: Mohr, 1984), 331. For Kim, this would include that 'Paul came to know that justification is by God's grace alone'. 
in Arabia, points out that Paul must have received further knowledge immediately. He was baptised in Damascus after his calling and even if

we should not yet presuppose any kind of institutionalized instruction along the lines of the later catechumenate - he must have received instruction in the basic content of belief in Jesus' before he 'called upon the Lord' in his baptism. ${ }^{115}$

\section{3) The similarities stem from a common knowledge of the OT}

There are several texts in the OT which speak of God's merciful forgiveness for his people (for example Hos. 11:8-9; Jer. 31:20; Isa $43: 1-7,22-25),{ }^{116}$ but Isaiah $52: 13-53: 12$ is the only OT text which speaks of 'justification', using exactly this terminology: Isaiah 53:11 (MT) speaks of the Servant of the Lord justifying the 'many', whose sins he bore. ${ }^{117}$ Is not this a likely source of Paul's teaching on justification? It is indeed: Paul applies the text about the Servant of the Lord in Isaiah 52:13-53:12 to Jesus in other places, like Romans 5:15, $19 ; 10: 16 ; 15: 1,11821$ and Philippians 2:7, to mention but a few. But as we have seen he also makes it clear that this application of Isaiah 53 to Jesus was not his own idea but part of the tradition he received (see 1 Corinthians 15:3-5).

\section{4) Paul took it over from Luke}

A fourth option would be that Paul or those who formulated the principle in Galatians 2:16 knew the tradition behind Luke 18:9-14.

\footnotetext{
115 Hengel and Schwemer, Paul, 45. Hengel points out that according to 2 Cor. 11:32, Paul returned to Damascus after his time in Arabia. This would be a second occasion where he could have received teaching about Jesus and his message.

${ }^{116}$ For a survey of justification in the Old Testament see Otfried Hofius, “"Rechtfertigung des Gottlosen" als Thema biblischer Theologie', in Paulusstudien, 2nd ed., WUNT 51 (Tübingen: Mohr, 1994), 121-147, esp. 133-142; Henning Graf Reventlow, Rechtfertigung im Horizont des Alten Testaments, BEvT 58 (Munich: Kaiser, 1971); Walther Zimmerli, 'Alttestamentliche Prophetie and Apokalyptik auf dem Wege zur "Rechtfertigung des Gottlosen", in Rechtfertigung: Festschrift für Ernst Käsemann zum 70. Geburtstag, ed. Johannes Friedrich, Wolfgang Pöhlman, and Peter Stuhlmacher (Tübingen: Mohr, 1976), 575-592; and the literature mentioned by Frey, 'Rechtfertigungstheologie', 552n7.

117 'After he has suffered, he will see the light of life and be satisfied; by his knowledge my righteous servant will justify many (יצדיק צדיק עבדי לרבים), and he will bear their iniquities.'

118 See Michael Thompson, Clothed with Christ: The Example and Teaching of Jesus in Romans 12.1-15.13, JSNTSup 59 (Sheffield: JSOT, 1991), 210-211.
} 
Options 3 and 4 are not mutually exclusive but may be combined to account for Paul's teaching on justification.

\subsection{Criteria for Assessing Allusions and Echoes to the Jesus Tradition}

Before we can claim any direct dependence of the principle Paul quotes in Galatians 2:16 and Romans 3:20-28 on Jesus's parable, we must lay out the criteria for identifying echoes of dominical tradition in Paul. Michael Thompson has done a lot of groundbreaking work in this field in his Clothed with Christ. ${ }^{119}$

1) We have to assess the 'place of the Gospel saying in the tradition' 120 and its claim to authenticity.

2) We need to discern 'whether a significant parallel exists between the two texts' and determine 'the likelihood of their relationship'. ${ }^{121}$ If there is a conceptual agreement while at the same time words take an unusual meaning, or are connected in a semantically unusual way, the likelihood of dependence is heightened. ${ }^{122}$

3) Finally, we need to we need to decide whether we are dealing with an allusion or an echo. 'Echoes', according to Thompson, are 'cases where the influence of a dominical tradition upon Paul seems evident, but where it remains uncertain whether he was conscious of the influence at the time of dictating'. ${ }^{123}$ Häusser points out that an echo could also be a connection to dominical tradition of which the author was aware but his readers might not have been. ${ }^{124}$

\section{1) The place of Luke 18 in the tradition}

We have already assessed the place of Luke 18:9-14 in the Gospel tradition: this parable is part of the material unique to Luke and has a Semitic ring to it. It has a strong claim to authenticity and we have good reasons to assume that it circulated among the early church long before Paul wrote his letters.

According to Riesner, the material unique to Luke, which is characterised by Semitisms, 'for the most part goes back to

\footnotetext{
119 Thompson, Clothed with Christ, 28-36.

120 Thompson, Clothed with Christ, 32.

121 Thompson, Clothed with Christ, 30.

122 Cf. Thompson, Clothed with Christ, 32 and Häusser, Christusbekenntnis, 56.

123 Thompson, Clothed with Christ, 30.

124 Häusser, Christusbekenntnis, 54.
} 
conservative Jewish Christians in Judaea and Jerusalem, from the circles around the Lord's brother James (cf. Acts 12:17)'. ${ }^{125}$ Many features of this tradition can be best understood if it came from the family of Jesus. ${ }^{126}$

\section{2) Possible historical links between Jesus and Paul}

We have already seen that there are significant parallels between the parable in Luke 18:9-14 and Paul's teaching on justification (see above, 5.1). The question is if and how Paul might have got to know such material. It has often been observed that Paul's writings have a special affinity to the material unique to Luke. One of the most obvious examples is the affinity between Paul's eucharistic tradition in 1 Corinthians 11:23-25 and that of Luke in 22:19-20. ${ }^{127}$ Paul is likely to have known something like Luke's passion narrative. ${ }^{128}$ Other features he shares with the tradition unique to Luke include Paul's wisdom Christology, the expectation that after a time of the Gentiles in Jerusalem there is new hope for Jerusalem (compare Luke 21:24 with Romans 11:25), ${ }^{129}$ the expectation that Jesus is not only the messiah for Israel, but as such 'a light for the Gentiles', ${ }^{130}$ and Paul's opinion on celibacy and marriage. ${ }^{131}$ In addition to that, Häusser has shown that

125 Rainer Riesner, 'Lukas (1. Jh. n. Chr.)', in Hauptwerke der Geschichtsschreibung, ed. Volker Reinhardt (Stuttgart: Kröner, 1997), 391-394, esp. 392 (my translation); Rainer Riesner, 'Prägung und Herkunft der lukanischen Sonderüberlieferung', ThBeitr 24 (1993), 228-248, esp. 244.

126 Riesner also points out various parallels between the NT letter of James and Luke's special tradition, e.g. the critique of the rich or the emphasis on wisdom (James $3: 13-18$; 1:5). For Mary as a bearer of tradition cf. Luke $2: 19$, 51, which contain

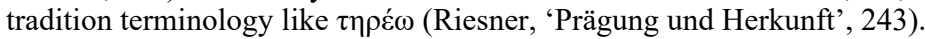

127 1 Cor. 11:23-26 and Luke 22:19-20 are not identical, but it is conspicuous that Paul's version in 1 Cor. 11 agrees with Luke's version much more than with the Markan one; see Peter Stuhlmacher, Jesus von Nazareth - Christus des Glaubens (Stuttgart: Calwer, 1988): 77, 81. According to Stuhlmacher, the chain of tradition can be traced from Jesus via the Jerusalem tradition about his last Passover to the protoLukan passion narrative. From there both Paul and Luke adopted it and adapted it for their respective purposes (Jesus von Nazareth, 102n17).

128 Cf. Hengel, 'Das Mahl', 451-495.

129 Riesner, 'Prägung und Herkunft', 232.

130 Compare Luke 2:32 and 4:27, where the Syrian Naaman is presented as an example to unrepenting Jews, to Rom. 1:16; 3:29 and others.

131 The material unique to Luke emphasises Jesus's divine wisdom (Luke 2:40, 52; 11:49); according to Paul Christ crucified is God's wisdom (1 Cor. 1:23-24; cf. Col. 1:15). Paul's life in celibacy and his opinion on marriage expressed in 1 Cor. 7:26-38 seem to fit in best with Luke's version of Jesus's saying on the reward of discipleship in Luke 18:29 (as opposed to Mark 10:29 and Matt. 19:29, which do not mention leaving one's wife) and Luke 20:34-35, according to which marriage is not part of the 
the pre-Pauline traditions in 1 Corinthians 15:3-5; Romans 1:3-4; Philippians 2:6-11 and Galatians 4:4-5 show an affinity not only to the material unique to Luke but also to Luke's version of the triple tradition. ${ }^{132}$ So there is no doubt that Paul had access to at least some of the traditions we only know from Luke otherwise. If Riesner's suggestion is true that the church in Damascus was founded by Jesus's relatives, ${ }^{133}$ Paul's closeness to these traditions could be easily explained.

But he could equally have received them in Jerusalem. Paul visited Jerusalem twice, according to Galatians 1:18-19 and 2:1 (compare Acts 9:26 and 11:30). ${ }^{134}$ It is true that he stresses 'the sacred independence of his missionary commission over against that of the other apostles' in Galatians 1:11, but this did not keep him from 'submitting his gospel to the Jerusalem 'pillars' for examination (compare 2:2) and from emphasizing that he preached the same gospel as they did (1 Cor. 15:11). ${ }^{135}$ The first of his visits to Jerusalem, his visit to Peter where he also met James, took place in around AD 36. This is long before his great missionary journeys (about $\mathrm{AD} 41$ to 46/47) and the writing of his letters (around AD 50 to 60 ). ${ }^{136}$ Both Peter and James could have passed on the tradition of Luke 18:9-14 to him. ${ }^{137}$ Silas, one of Paul's

heavenly existence to come (slightly less trenchant in Matt. 22 and Mark 12). The fact that in Luke 10 it is a Samaritan who fulfils the love commandment calls to mind Rom. 2:26. See Riesner, 'Prägung und Herkunft', 231-238.

132 Häusser, Christusbekenntnis, 354.

133 Rainer Riesner, 'Back to the Historical Jesus through Paul and His School', JSHJ 1 (2003), 171-199. The fact that Acts 11:19-20 does not mention Damascus speaks against Hengel and Schwemer's opinion (Paul, 85) that the church there was founded by Jewish-Christian Hellenists (against this view see Häusser, Christusbekenntnis, 357).

${ }^{134}$ Hengel and Schwemer, Paul, 147 consider the possibility that at least some of the content of 1 Cor. 15:3-8 was passed on at this particular occasion.

135 Stuhlmacher, Revisiting, 21.

136 See the chronological table in Hengel and Schwemer, Paul, xi-xiv.

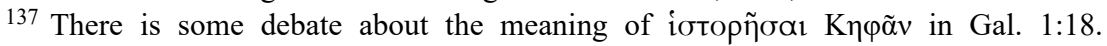
Whether or not James D. G. Dunn is right in saying that "in our period the thought of

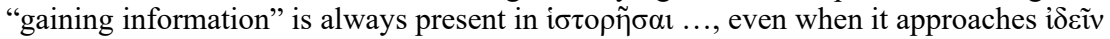
in usage' ('The Relationship between Paul and Jerusalem according to Galatians 1 and 2', NTS 28 [1982], 461-478, esp. 465-66), which Hofius denies for the Hellenistic

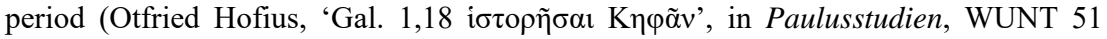
[Tübingen: Mohr, 1989], 255-267, esp. 261). Even just 'getting to know' Peter would have involved learning from him what had shaped him most: the experience of his three years with Jesus (see J. D. G. Dunn, The Theology of Paul, the Apostle (Edinburgh: T\&T Clark, 1998), 188 and Hengel and Schwemer, Paul, 144-150). We have to keep in mind the purpose of Gal. 1:11-24: Paul needed to substantiate his 
closest co-workers, also came from Jerusalem. The same is true of Barnabas, a close companion of Paul for several years (Acts 11:2226). ${ }^{138}$

The third place we have to consider as a possible source of Jesus tradition for Paul is Antioch. The founders of this church came from Jerusalem (Acts 11:19-20). ${ }^{139}$ Paul came to Antioch on the initiative of Barnabas in about $\mathrm{AD} 40^{140}$ and worked there for a year (see Acts 11:25-26; 13:1; 14:28 and Galatians 1:21; 2:11, where Paul mentions his sojourns in Syria and Antioch). ${ }^{141}$ Acts 11:25 ('Barnabas went to Tarsus to look for Saul') indicates that Barnabas knew Paul even before they worked together in Antioch. Both Barnabas and Paul were supporters of the Gentile mission without circumcision and observance of the Law in Antioch (Acts 15:1-6).

We can now answer the question whether Paul could have known the parable in Luke 18 with more confidence: there are several paths the tradition could have taken from Jesus to Paul, even if we do not know for sure which one it took.

\section{3.) Allusion or echo?}

The principle in Galatians 2:16 is a very general statement and there is no explicit reference to the parable. We are certainly not dealing with an allusion to dominical tradition, which the readers were supposed to recognise as such. But we have reason to believe that whoever was the

independence from Jerusalem. In such a context, even the concession that he did spend 15 days with Peter is quite remarkable. That he did not choose a verb which implies zealous enquiries more strongly, however, is not astonishing.

${ }^{138}$ Luke portrays Barnabas as an early member of the Jerusalem church in Acts 4:36. His close connection to Jerusalem is shown once again in Gal. 2:13, where Barnabas sides with the other Jewish Christians in Antioch and with Peter (see Hengel and Schwemer, Paul, 215). This will be the reason why the church in Antioch sent him (together with Paul) to Jerusalem as their messengers twice (Acts 11:30; 15:2). It is people like him who first brought the Jesus tradition to Antioch and who could also hand it down to Paul. According to Hengel, Barnabas might even have known Jesus personally (Paul, 218).

139 Antioch stayed in close contact with Jerusalem, as the sending of Barnabas (Acts 11:22-24), the visit of prophets from Jerusalem (Acts 11:27) and of certain Judaising brothers (Acts 15:1) show.

140 See Hengel and Schwemer, Paul, 205.

${ }^{141}$ Hengel and Schwemer, Paul, 205-221. Therefore Lindemann's agnosticism concerning Antioch as a place where Paul could have learnt Jesus tradition is unwarranted (see his 'Paulus und die Jesustradition', 306). No historian can confine himself to what is explicitly written. He will always have to infer from other sources (in the case of Paul's history mainly Luke's Acts - see Stuhlmacher, Biblische Theologie 1, 226-228; Hengel, Schwemer, Paul, 15-21) and from common sense. 
first to formulate this principle did so on the basis of Jesus's parable. Whether Paul knew the dominical tradition behind it is difficult to tell. But since he seems to make use of it beyond the quotations of the traditional principle on justification it is most likely that he did know it. The way the whole cluster of ideas in Romans 3:20-28 is congruent with the parable points in this direction.

\subsection{Accounting for the Differences between Luke 18 and Paul's Doctrine of Justification}

It is true - as Stuhlmacher emphasises - that the

apocalyptic breadth of the doctrine of justification must not be diminished by limiting the gospel of God's righteousness to the message of the forgiveness of sins for individual sinners. ${ }^{142}$

But it is equally true that the two basic statements on justification in Galatians 2:16 and Romans 3:28, which Paul quotes approvingly, speak of the salvation of individuals. In Romans 4:6-8 Paul defines justification by faith and by grace as the forgiveness of sins, which is 'the anticipation of acquittal in the last judgment'. ${ }^{143}$ In Romans 6:7 he says that 'anyone who has died has been justified from sin'

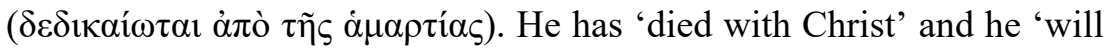
also live with him' (6:8). This is exactly how Luke summarises Paul's preaching in Acts 13:38-39: having said that 'through Jesus the forgiveness of sins is proclaimed to you' he explains this in the following way:

Through him everyone who believes is justified from every sin, a justification you were not able to obtain under the law of Moses (àrò

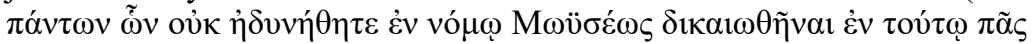

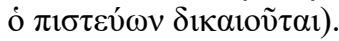

For Paul for an individual sinner 'to be justified' means that they are newly created through the forgiveness of sins brought about by atonement. If the tax collector did think of forgiveness through the atoning sacrifice in the Temple, this would be exactly what he prayed for and was granted. It was the eschatological fulfilment of the Temple

142 Stuhlmacher, Revisiting, 28. 'What is involved in the demonstration of God's righteousness through the atoning death of Christ and in his resurrection for the justification of many and in his ongoing activity as Lord, Advocate, Savior and Judge of the world is nothing less than the establishment of the right of God over the whole cosmos.'

143 Jeremias, 'Paul and James', 369. 
cult through Jesus's death and resurrection that led the early Church to see his cross as the eschatological $i \lambda \alpha \sigma \tau$ ípเov or place of atonement (Romans 3:25). But because he anticipated this eschatological fulfilment, Jesus could forgive sins even before Easter (for instance Mark 2:5).

To say that Luke 18 is at the root of Paul's teaching on justification is not to claim that there has been no further development afterwards. After all, Luke 18 is 'only' a parable. It does not draw out all the implications of justification. For example, there is also a striking absence of any remark on restitution or a change of life on the part of the tax collector, which would have been the equivalent of 'faith expressing itself through love' (Gal. 5:6). ${ }^{144}$ Nor is his final acquittal in judgement mentioned clearly (it is hinted at in Luke 18:14b), whereas Paul knows that he himself has not yet reached the goal (Phil. 3:12; Gal. 5:5) and is in need of Jesus's intercession up unto the day of final judgement (Rom. 8:34).

If we blend justification as it is portrayed in Luke 18 with the sayings of Jesus concerning the ransom necessary in the final judgement but impossible for humans to provide (Mark 8:37 and parallels), Jesus's own readiness to surrender his life in death as a ransom for Israel (Mark 10:45 paralleled with Isa. 43:3), and the words of institution at the Lord's Supper (Mark 14:24 and parallels), we are not far from Paul's statements on justification in 2 Corinthians $5: 17-21 .{ }^{145}$

\section{Conclusion}

We started by asking whether Paul invented justification by faith, possibly at a comparatively late stage of his missionary career? From what we have found we can answer this question with a clear 'no'. We have seen that his teaching on justification does not only emerge in his later letters, Romans and Philippians. It is already presupposed in the Corinthian correspondence. Galatians with its very clear justification statements is probably not a late letter of Paul's, but a very early one. In Galatians 2:16 and Romans 3:28 we find traditional statements on justification, which Pauls claims to have known and used as an

\footnotetext{
144 In Luke 19:8 Zacchaeus offers to make restitution.

145 Stuhlmacher, Revisiting, 57.
} 
argument in his dispute with Paul at Antioch as early as AD 48, and which he possibly even knew when he became a believer.

The first person to apply the OT expectation of the Servant of the Lord in Isaiah 53 to Jesus's life and death was Jesus himself (Mark 10:45 and the eucharistic tradition). The formula in 1 Corinthians 15:3-5 shows that his own interpretation of his death was taken up by the apostles, who handed it down to the early church and also to Paul. While the acceptance of sinners characterises Jesus's whole ministry, there is one text, and only one, in the Jesus tradition which speaks about the justification of sinners: the parable of the Pharisee and the tax collector in Luke 18:9-14. Since it contains several Semitisms, it has a strong claim to authenticity.

The conceptual congruity between Luke 18:9-14 on the one hand and Galatians 2:16 and Romans 3:28 on the other make it very likely that those who formulated these statements on justification did so with this parable in mind. Since Romans 3:20-28 contains a whole cluster of ideas which agree with this parable, it is well possible that Paul himself knew it. Historically, we have no reason to preclude that he had access to it.

\section{Appendix: Literature on 'Jesus and Paul'}

\section{Literature arguing that there is hardly any historical continuity and no significant theological congruity between Jesus and Paul}

Becker, Jürgen, Paulus, der Apostel der Völker (Tübingen: Mohr, 1989).

Hahn, Ferdinand, Theologie des Neuen Testaments, vol. 1 (Tübingen: Mohr Siebeck, 2002).

Lindemann, Andreas, 'Paulus und die Jesustradition', in Jesus, Paul, and Early Christianity: Studies in Honour of Henk Jan de Jonge, ed. R. Buitenwerf, Harm W. Hollander and Johannes Tromp, NTSup 130 (Leiden: Brill, 2008), 281-316.

Neirynck, Frans, 'Paul and the Sayings of Jesus', in L'Apôtre Paul: personnalité, style et conception du ministère, ed. A. Vanhoye et al., BETL 73 (Leuven: University Press, 1986), 265-321.

Schmithals, Walter, 'Paulus und der historische Jesus', ZNW 53 (1962), 145-60.

Strecker, Georg, Theologie des Neuen Testaments, ed. and completed by Friedrich W. Horn (Berlin: de Gruyter, 1995).

Tuckett, Christopher M., '1 Corinthians and Q', JBL 102 (1983), 607-18; 'Paul and the Synoptic Mission Discourse?' EThL 60 (1984), 376-81; 'Synoptic Traditions in 1 Thessalonians', in The Thessalonian Correspondence, ed. R. F. Collins, BETL 87 (Leuven: University Press, 1990), 160-82. 
Walter, Nikokaus, 'Paulus und die urchristliche Jesustradition', NTS 31 (1985), 498-522.

\section{Literature arguing that while there is not necessarily a historical continuity there is significant theological congruity between Jesus's proclamation of the kingdom and Paul's teaching on justification}

Braun, Herbert, 'Hebt die heutige neutestamentlich-exegetische Forschung den Kanon auf?' in Herbert Braun, Gesammelte Studien zum Neuen Testament und seiner Umwelt (Tübingen: Mohr, 1962), 310-24.

Bultmann, Rudolf, 'Die Bedeutung des geschichtlichen Jesus für die Theologie des Paulus' in Glauben und Verstehen I, 2nd edn. (Tübingen: Mohr, 1954), 191-213.

Jüngel, Eberhard, Paulus und Jesus: eine Untersuchung zur Präzisierung der Frage nach dem Ursprung der Christologie (Tübingen: Mohr, 1962).

Lohse, Eduard, Paulus: Eine Biographie (München: Beck, 1996).

Schnelle, Udo, Paulus. Leben und Denken (Berlin: de Gruyter, 2003).

\section{Literature arguing for a historical continuity leading to theological congruity}

Allison, D. C., Jr., 'Paul and the Missionary Discourse', EThL 61 (1985), 369-75; 'The Pauline Epistles and the Synoptic Gospels: The Pattern of the Parallels', NTS 28 (1982), 1-32.

Barnett, Paul, Paul, Missionary of Jesus (Grand Rapids, MI: Eerdmans, 2008).

Bruce F. F., Jesus and Paul (London: SPCK, 1977).

Dunn, James D. G., 'Jesus Tradition in Paul', in Studying the Historical Jesus, ed. Bruce D. Chilton and Craig Evans (Leiden: Brill, 1994), 155-78; 'Paul's Knowledge of the Jesus Tradition: The Evidence of Romans', in Christus bezeugen: Festschrift für Wolfgang Trilling, ed. Karl Kertelge, Traugott Holtz, and Claus-Peter März (Leipzig: St Benno, 1990), 193-207; 'The Relationship between Paul and Jerusalem according to Galatians 1 and 2', NTS 28 (1982), 461-78; 'Mark 2:1-3:6: A Bridge between Jesus and Paul on the Question of the Law', in Jesus, Paul and the Law: Studies in Mark and Galatians (London: SPCK, 1990), 10-36.

Häusser, Detlef, Christusbekenntnis und Jesusüberlieferung bei Paulus, WUNT 2.210 (Tübingen: Mohr Siebeck, 2006).

Hengel, Martin, 'Das Begräbnis Jesu bei Paulus und die leibliche Auferstehung aus dem Grabe', Studien zur Christologie: Kleine Schriften, vol. 4, WUNT 201 (Tübingen: Mohr Siebeck, 2006), 386-450; 'Das Mahl in der Nacht, "in der Jesus ausgeliefert wurde" (1 Kor 11, 23)' in Studien zur Christologie: Kleine Schriften, vol. 4, WUNT 201 (Tübingen: Mohr Siebeck, 2006), 451-95.

Jeremias, Joachim, 'Paul and James', ET 66 (1954-55), 368-71.

Lee, Yongbom, The Son of Man as the Last Adam: the Early Church Tradition as a Source of Paul's Adam Christology (Eugene, OR: Pickwick, 2012).

Longenecker, Bruce W., 'Good News to the Poor: Jesus, Paul and Jerusalem', in Jesus and Paul Reconnected, ed. T. Still (Grand Rapids, MI: Eerdmans, 2007): 37-66.

Riesner, Rainer, 'Paulus und die Jesus-Überlieferung' in Evangelium, Schriftauslegung, Kirche: Festschrift für Peter Stuhlmacher zum 65. Geburtstag, 
ed. Jostein Ådna, Scott J. Hafemann, and Otfried Hofius (Göttingen: Vandenhoeck \& Ruprecht, 1997), 347-65; Die Frühzeit des Apostels Paulus: Studien zur Chronologie, Missionsstrategie und Theologie, WUNT 71 (Tübingen: Mohr, 1994); 'Jesus, Paulus und wir', ThBeitr 45 (2014), 6-15.

Schlatter, Adolf, Jesus und Paulus: eine Vorlesung und einige Aufsätze: Mit einem Geleitwort von Paul Althaus, 3rd edn; (Stuttgart: Calwer, 1961).

Senft, Christophe, Jésus de Nazareth et Paul de Tarse, (Geneva: Editions Labor et Fides, 1985); Jésus et Paul: qui fut l'inventeur du christianisme? (Geneva: Editions Labor et Fides, 2002).

Seyoon, Kim, 'Sayings of Jesus', in Dictionary of Paul and His Letters, ed. G. F. Hawthorne, R. P. Martin, and D. G. Reid (Downers Grove, IL: InterVarsity, 1993), 474-92; 'The Jesus Tradition in 1Thess. 4:13-5:11', NTS 48 (2002), 225-42; Paul and the New Perspective: Second Thoughts on the Origin of Paul's Gospel, WUNT 14 (Tübingen: Mohr Siebeck, 2002).

Stuhlmacher, Peter, 'Jesustradition im Römerbrief?', ThBeitr 14 (1983), 240-50.

Thompson, Michael, Clothed with Christ: The Example and Teaching of Jesus in Romans 12:1-15:13, JSNTSup 59 (Sheffield: JSOT Press, 1991).

Wenham, David, 'The Rock on Which to Build: Some Mainly Pauline Observations about the Sermon on the Mount,' in Built Upon the Rock. Studies in the Gospel of Matthew, ed. Daniel M. Gurtner and John Nolland (Grand Rapids, MI: Eerdmans, 2008); Paul and Jesus: The True Story (London: SPCK, 2002); Paul: Follower of Jesus or Founder of Christianity? (Grand Rapids, MI: Eerdmans, 1995); 'Paul's Use of the Jesus Tradition: Three Samples' in Gospel Perspectives, Vol. 5: The Jesus tradition outside the Gospel, (Sheffield: JSOT Press, 1984), 7-37; Gospel Perspectives, Vol. 4, The Rediscovery of Jesus' Eschatological Discourse (Sheffield: JSOT Press, 1984); 'The Story of Jesus Known to Paul' in Jesus of Nazareth: Lord and Christ: Essays on the Historical Jesus and New Testament Christology, ed. Joel B. Green and Max Turner (Grand Rapids, MI: Eerdmans, 1994), 297-311; Did St Paul Get Jesus Right? The Gospel according to Paul (Oxford: Lion Hudson, 2010).

Westerholm, Stephen, 'Law and Gospel in Jesus and Paul', in Jesus and Paul Reconnected, ed. T. Still (Grand Rapids, MI: Eerdmans, 2007), 19-36.

Witherington, Ben, Jesus, Paul, and the End of the World: A Comparative Study in New Testament Eschatology (Exeter: Paternoster, 1992).

Yeung, Maureen, Faith in Jesus and Paul: A Comparison with Special Reference to 'Faith That Can Remove Mountains' and 'Your Faith Has Healed/Saved You', WUNT 2.147 (Tübingen: Mohr Siebeck, 2002). 